\title{
Relevance of the ECtHR's Case-law on the Right to Judicial Review - A Story of Three Models
}

A few matters need to be highlighted about the case-law of the ECtHR analysed above. This case-law brings to light a problem common to many European states and the difficulty that the ECtHR had to provide a harmonious interpretation for the right to an effective judicial remedy.

First, even if Article 13 ECHR provides expressly for the right to an effective remedy and for what can be deemed as a wider framework for interpretation, most cases considered by the ECtHR raising concerns about intensity of judicial review are decided under Article 6(1) ECHR. The ECtHR analyses these cases as a breach of the right of access to a court or as a breach of the right to a fair trial. This approach renders the ECtHR's analysis more harmonious because it allows the Court to link judicial review to other safeguards guaranteed by Article 6(1) ECHR, such as independence and the right to be heard. More importantly, it grounds the analysis on judicial review within the terrain of the fairness of justice.

Second, as ECtHR noted in Bryan, administrative law appeals that encompassed only a review of legality are common practice in the member states parties to the ECHR. ${ }^{1}$ Despite what appears to be a consensus of practice, the ECtHR does not consider the deference to administrative agency and the review of legality to be compatible with the ECHR. At the same time, the ECtHR does not provide for a blanket rejection of this type of administrative law appeals, but follows a case-by-case reasoning.

Third, applicants who complain at the ECtHR about the insufficiency of judicial review performed by the domestic courts in administrative law appeals also tend to complain about the lack of independence of the administrative agency whose decision the applicant is trying to set aside or about a breach of the right to be heard. This fact indicates that applicants expect administrative agencies performing adjudicative functions to behave in the same way as courts. This also indicates that applicants consider that courts should control the excessive exercise of administrative discretion.

1 Bryan v. the United Kingdom, quoted above. 
Lastly, I have distilled three models of judicial review from the case-law of the ECtHR. These models are based on a causal relation between the quality of the administrative discretion exercised, the impact of the discretion on the individual interests concerned and, lastly, the depth of judicial review. The first model is concerned with the exercise of administrative discretion within polycentric issues. The second model describes the exercise of administrative discretion in monocentric issues. The third model deals with the exercise of administrative discretion as police power.

I describe the proposed models in the following sections.

\subsection{Exercise of Administrative Discretion within Polycentric Issues}

Modern democracies witnessed an increase in the exercise of administrative discretion for the purpose of achieving wider policy aims. Such discretion is closely associated with political agendas of elected officials. It can be argued that the exercise of administrative discretion for wider policy-making purposes is mandated by the electorate and, thus, part of democratic processes.

An example of this type of administrative discretion would be when individual expropriations are performed in order to construct a highway or a nuclear power plant. In these cases, the professional knowledge of the administrative agency plays an important role. So does the undisturbed exercise of the discretionary powers by the administrative agency. Also, such situations might be the result of both lengthy and costly political processes.

This situation falls under what Fuller and Winston have famously coined as a polycentric issue: "we might visualize this kind of situation by thinking of a spider web. A pull on one strand will distribute tensions after a complicated patter throughout the web as a whole". 2

Individual interests will often be affected by the exercise of this kind of administrative discretion. However, judicial review might not be the best tool to comprehensively address the affected individual interests. An in-depth judicial review of such cases can block the contested policy. In the example above, if the domestic courts choose to perform an in-depth judicial review and to annul the administrative decision, this might delay the construction of the highway or of the nuclear power plant. At the same time, since a policy decision like the decision to build a highway or a nuclear power plant involves

2 Fuller, L. L., and K.I. Winston. "The Forms and Limits of Adjudication." Harvard Law Review 92.2 (1978), pp. 353-409. 
hundreds of experts and thousands of working hours, re-hearing such a case during judicial review by only a handful of judges might not appear to be in line with fairness either.

The ECtHR provides that in such cases judicial review should start by clarifying whether the subject-matter of the individual case - that is the factual basis of the case - is disputed. In the example above, this would involve analysing whether the fact of expropriation is disputed. Furthermore, as Bryan provides, the sufficiency of judicial review should be assessed depending on the manner in which the decision was reached, the content of the dispute and the possibility to review the shortcomings in the administrative procedure. $^{3}$

What is important in this case is that the individual directly affected by the wider policy aims is heard during all stages of the procedure and is compensated for the loss he/she incurs. In other words, the purpose of this type of judicial review is to ensure that administrative discretion is exercised fairly and that those affected by this exercise are not simply dismissed as nuisances.

Two features would greatly increase the fairness of proceedings involving this type of administrative discretion. First, the early stages of the policymaking process must include an assessment of the individual interests that might be affected by it. Citizens and their interests should be seriously considered and mediators should be involved in reaching agreement about contentious issues. This communitarian aspect of the exercise of administrative discretion could diminish the risk of court proceedings because, unless serious evidence of arbitrariness, courts would not satisfy the individual interest due to the limited judicial review that they would perform. Avoiding court proceedings by having properly considered the individual interests involved would thus be a win solution for all parties involved.

Second, having an independent adjudicative branch within the administrative agency enjoying wide discretionary powers would answer all the competing needs that arise in such a context: the administrative agency would have its policy enforced without unnecessary delays, the individuals affected would have their interest considered and loss compensated and the courts would be relieved of a case.

The exercise of administrative discretion within polycentric issues that satisfy the requirements described above would be compatible with even the broadest notion of fairness.

3 Bryan $v$. the United Kingdom, quoted above. 


\subsection{Exercise of Administrative Discretion for Monocentric Issues}

The opposite of polycentric issues are monocentric issues, that is cases in which administrative discretion in exercised and affects only one individual case. This could concern the dismissal of a staff member, the allocation of social benefits or the insolvency of a bank. Monocentric issues are classical, textbook examples of exercise of administrative discretion.

In these instances, there should be no political capital involved. Less people and resources are involved in the decision-making process and the disputed administrative process is normally regulated by employment law, social benefits laws or insolvency law. An example could be when a citizen is deprived of social benefits by an administrative agency.

Such cases may result in court proceedings either because the administrative authority has made a mistake, or because there is a gap in the relevant normative framework. It might be that the exercise of administrative discretion in this type of individual cases involves specialized knowledge, such as during insolvency proceedings. This fact however does not justify a self-restrained judicial review. On the contrary, the domestic courts can in this case correct mistakes, assess the exercise of the discretionary power in relation to the individual concerned or fill the gap in the normative framework.

Cases of exercise of administrative discretion in monocentric issues - as shown in Tsfayo - require a judicial review both of the process of administrative decision making and of the reached decision. ${ }^{4}$ Such judicial review should also be able to either re-consider the case or send the case for reconsideration by the administrative authority.

Full judicial review of cases involving monocentric issues performs the important role of quality control of the administrative decisions. When administrative authorities know that their decisions may be reversed or resent for reconsideration, they will be more diligent in the performance of their tasks.

According to the ECtHR, the limited judicial review of the exercise of administrative discretion in monocentric issues is not be compatible with the right to a fair trial.

4 Tsfayo v. the United Kingdom, quoted above. 


\subsection{Exercise of Administrative Discretion as Policing Power}

Modern democracies have decriminalized certain fields of law, such as petty offences. Also, partially, economic law offences stopped being considered criminal offences and became instead administrative law offences.

A paradox, however, came to occupy these areas of law. On the one hand, despite removing the "criminal law" tag, the administrative agencies entrusted with enforcing economic law have been empowered with important policing powers. Thus, they can launch investigations, they can search premises, cars and houses, they can seize documents, they can collect and corroborate evidence, they can accuse and fine the offender. On the other hand, the removal of the "criminal law" tag from the economic law offences did not change the extent to which individuals' rights are affected during such proceedings. The paradox has been, both in the policy-making circles and in the academic circles, to treat such proceedings as administrative law despite the bold policing powers exercised by administrative agencies and the effect on individuals' rights. This paradox extended to the exercise of judicial review over such matters. It was expected that courts perform a limited, self-restrained judicial review of administrative action by deferring to the discretion of the administrative agency. In fact, judicial review of economic offences is expected to treat the exercise of administrative discretion as if it concerned polycentric issues.

Another issue which is ignored under this paradox is the fact that the administrative discretion exercised under this model is the most dangerous. Competition law offers a good way to exemplify this assertion. A competition agency typically has the discretion to decide which cartels or abuses of dominant position to pursue and when to pursue them. It is, for example, difficult to imagine a prosecutor who would selectively pursue cases of homicide. Such prosecution is, unfortunately, practiced in countries considered not democratic. However, when competition agencies select which competition law offences to pursue and which not to pursue, they are acting like the prosecutor described above.

This type of exercise of administrative discretion may be the expression of political goals or personal preferences. In addition, the individuals whose rights have been violated during the administrative proceedings should have a forum to complain about the violation of those rights or about the exercise of administrative discretion. For these reasons, the judicial review performed in these cases should be bold and deep in order to assess the exercise of administrative discretion and the respect of the individuals' rights. 
The case-law of the ECtHR is clear in this respect. The ECtHR provides that when administrative discretion is exercised in areas that fall under the criminal head of Article 6(1) ECHR, domestic courts should perform a full judicial review. A full review includes the power to hear evidence, the power to quash in all respects and the power to substitute the reasoning of the administrative agency with its own reasoning. These powers should be provided by the domestic legislation and, more importantly, should be exercised in practice. 